\title{
List of Illustrations
}

frontispiece: Ford Madox Brown, An English Autumn Afternoon

(1852-54).

1. Roger Fenton, Kew Ait.

2. John Spiller and Dr. Percy, The New Mill, Near Lynton, North Devon.

3. Francis Frith, Holy St. Mill, Chagford.

4. Francis Bedford, untitled.

5. Francis Bedford, Dolgelley, View in Torrent Walk.

6. Francis Frith, Stennage Valley.

7. Roger Fenton, The Valley of Nant-Frangen, North Wales.

8. Francis Frith, The Prebend's Bridge, Durham.

9. Frederick Evans, Durham Cathedral: From Banks of River Wear.

10. W. H. Fox Talbot, Melrose Abbey.

11. Roger Fenton, Tintern Abbey.

12. Philip H. Delamotte and Joseph Cundall, Fountains Abbey.

13. Philip H. Delamotte and Joseph Cundall, Rivaulx Abbey.

14. Francis Frith, Knaresborough Castle.

15. Francis Bedford, Llanberis, Dolbadarn Castle and Pass.

16. Ernest Edwards, Cleft in the Rock: Anchor Church, Derby.

17. J. D. Llewelyn, Piscator No. 2.

18. Major F. Gresley, untitled.

19. Major F. Gresley, Shade.

20. Francis Bedford, Cedar at Warwick Castle.

21. Earl of Caithness and Bembridge of Windsor, Great Beech on Manor Hill.

22. Frederick Evans, Crépuscule au Printemps: France.

23. Frederick Evans, Near Shore.

24. Henry Peach Robinson, Feeding the Calves.

25. Labourer's Cottage.

26. Birket Foster, The Old Chair Mender.

27. Mrs. Helen Allingham, Cottage at Chiddingford, Surrey.

28. Samuel Palmer, Farmyard Near Princes Risborough.

29. J. C. Loudon, Villa.

30. J. C. Loudon, Fountain, Napoleon Willow, and Arch Tent.

31. John Nash, Park Village East, Regent's Park.

32. Hayley and Brown, Hanover Square and Zoological Gardens, Broughton near Manchester.

33. Sir Edwin Landseer, Victoria, Albert, and the Princess Royal at Windsor.

34. G. G. Scott and W. H. Crossland, Akroydon Model Village, Halifax.

35. John Nash, Blaise Hamlet, near Bristol. 
36. Joseph Paxton, Birkenhead Park, near Liverpool.

37. J. C. Dollman, The Avenue, Bedford Park.

38. J. T. Carr, Tower House and Queen Anne's Grove, Bedford Park.

39. Park and Unwin, Hampstead Garden Suburb from the Heath Extension.

40. William Gilpin, Scaleby Castle.

41. Scaleby Castle.

42. Cottage.

43. Brantwood.

44. Brantwood.

45. Interior: Brantwood.

46. William Morris, wallpaper design.

47. William Morris, wallpaper design.

48. William Morris, wallpaper design.

49. Papier mâché bed.

50. M. H. Baillie Scott, "rose" bedstead.

51. M. H. Baillie Scott, cabinet.

52. M. H. Baillie Scott, window, Blackwell.

53. M. H. Baillie Scott, stained glass, Blackwell.

54. M. H. Baillie Scott, door at Blackwell.

55. M. H. Baillie Scott, stenciled mountain ash, Blackwell.

56. M. H. Baillie Scott, tree-colonettes, Blackwell.

57. C. F. A. Voysey, Broadleys.

58. M. H. Baillie Scott, interior landscape, Blackwell.

59. C. F. A. Voysey, wallpaper frieze.

60. C. F. A. Voysey, The Snake.

61. W. Westall and Lt. Beechey, Ships in Winter Harbour.

62. David Caspar Friedrich, Die Gescheiterte Hoffnung.

63. Burford's Panorama of the Polar Regions.

64. Sir Edwin Landseer, Man Proposes, God Disposes.

65. J. M. W. Turner, The Alps at Daybreak.

66. Elijah Walton, The Weisshorn from the Riffel.

67. James Mahoney, Fog-Bow Seen from the Matterhorn.

68. A. M. W. Adams Reilly, The Western Face of Mont Blanc.

69. John Martin, Manfred on the Jungfrau.

70. J. D. Forbes, Mont Cervin.

71. John Ruskin, The Aiguilles of Chamonix.

72. Ernest Edwards, The Nesthorn from the Ober Aletsch Glacier.

73. Lucy Wills, Ascent of the Wetterhorn.

74. Elijah Walton, Alpine Climbers.

75. John Leech, Marley's Ghost.

76. John Leech, The Spirit of Christmas Present.

77. John Leech, Scrooge and Bob Cratchit. 
78. "Lord, Keep My Memory Green" (The Haunted Man).

79. Sir A. W. Callcott, Diana at the Chase.

80. John Brett, Val d'Aosta.

81. John Constable, Stoke-by-Nayland.

82. James Abbott McNeill Whistler, Nocturne in Blue and Gold:

Old Battersea Bridge.

83. J. M. W. Turner, Norham Castle, Sunrise.

84. Edward Lear, Finale.

85. Thomas Girtin, Kirkstall Abbey-Evening.

86. John Sell Cotman, Chirk Aqueduct.

87. Samuel Palmer, In a Shoreham Garden.

88. William Holman Hunt, Hawthorn and Bird's Nest.

89. Peter De Wint, Gloucester.

90. William Dyce, Pegwell Bay, Kent.

91. Miles Birket Foster, The Milkmaid.

92. William Holman Hunt, The Hireling Shepherd.

93. J. E. Millais, Ophelia.

94. Arthur Hughes, The Long Engagement.

95. Dante Gabriel Rossetti, The Girlhood of Mary Virgin.

96. Dante Gabriel Rossetti, Ecce Ancilla Domini!

97. J. E. Millais, Mariana.

98. Charles Allston Collins, Convent Thoughts.

99. William Holman Hunt, Valentine Rescuing Sylvia.

100. William Holman Hunt, The Lady of Shalott.

101. William Holman Hunt, The Lady of Shalott.

102. Dante Gabriel Rossetti, The First Anniversary of the Death of Beatrice.

103. Dante Gabriel Rossetti, The First Anniversary of the Death of Beatrice.

104. William Holman Hunt, The Awakened Conscience.

105. Dante Gabriel Rossetti, study for Found.

106. J. E. Millais, Mariana.

107. Dante Gabriel Rossetti, The Lady of Shalott.

108. Dante Gabriel Rossetti, The Palace of Art.

109. Dante Gabriel Rossetti, The Palace of Art.

110. Atkinson Grimshaw, The Seal of the Covenant.

111. James Thomas Linnell, The Rainborv.

112. Daniel Maclise, Noah's Sacrifice.

113. Gustave Jäger, Noah's Sacrifice.

114. Francis Danby, The Deluge.

115. Gustave Doré, The World Destroyed by Water.

116. Ford Madox Brown, Walton-on-the-Naze. 
117. J. E. Millais, The Blind Girl.

118. William Holman Hunt, The Scapegoat (first version).

119. J. M. W. Turner, The Wreck Buoy.

120. Fountain at Ampfield.

121. Hursley Vicarage and Church.

122. From Isaac Williams, The Altar.

123. From Isaac Williams, The Altar.

124. From Isaac Williams, The Altar.

125. From Isaac Williams, The Baptistery.

126. From Isaac Williams, The Baptistery.

127. From Isaac Williams, The Baptistery.

128. From Isaac Williams, The Baptistery.

129. Sir Max Beerbohm, William Wordsworth.

130. J. Gilbert, We Are Seven.

131. Birket Foster, We Are Seven. 